Artículo científico

(Original paper)

\title{
VEGETAL SYNERGISTS FOR TRAPPING THE ADULT OF SCYPHOPHORUS ACUPUNCTATUS GYLLENHAL, IN PHEROMONE BAITED TRAPS, IN AGAVE ANGUSTIFOLIA HAW., IN MORELOS, MEXICO
}

\author{
SINERGISTAS VEGETALES PARA LA CAPTURA DEL ADULTO DE SCYPHOPHORUS \\ ACUPUNCTATUS GYLLENHAL, EN TRAMPAS CON FEROMONA, EN AGAVE \\ ANGUSTIFOLIA HAW., EN MORELOS, MÉXICO
}

\begin{abstract}
JuAn José CRUZ FAUSTINO ${ }^{1}$, PEdro FIGUEROA CASTRO ${ }^{2 *}$, José ÁNGEl ALCÁNTARA JIMENÉZ ${ }^{1}$, VÍCTOR LÓPEZ MARTÍNEZ ${ }^{3}$, FRANCISCA SILVA GARCÍA ${ }^{3}$

${ }^{1}$ Colegio Superior Agropecuario del Estado de Guerrero, Centro de Estudios Profesionales. Carretera Iguala-Cocula Km. 14.5, Guerrero, México.<jjcruz_tauro@hotmail.com>; <aaja61@ @otmail.com>

${ }^{2}$ Investigación y Soluciones Agrícolas Agriminilla S. A. S., Avenida Cirina Mata 122A, Col. Centro, Quetzalapa, C.P. 40142, Guerrero, México. <agriminilla@gmail.com>

${ }^{3}$ Universidad Autónoma del Estado de Morelos, Facultad de Ciencias Agropecuarias, Av. Universidad 1001, Col. Chamilpa, CP 62209, Cuernavaca, Morelos, México. <victor.lopez@uaem.mx>; 〈fran_silva19@yahoo.com.mx>

*Autor para correspondencia: <agriminilla@gmail.com>
\end{abstract}

Recibido: 26/02/2019; aceptado: 13/06/2019; publicado en línea: 16/08/2019

Editor responsable: Magdalena Cruz Rosales

Cruz-Faustino, J. J., Figueroa-Castro, P., Alcántara-Jiménez, J. A., López-Martínez, V., SilvaGarcía, F. (2019) Vegetal synergists for trapping the adult of Scyphophorus acupunctatus Gyllenhal, in pheromone baited traps, in Agave angustifolia Haw., in Morelos, Mexico. Acta Zoológica Mexicana (nueva serie), 35, 1-9. https://doi.org/10.21829/azm.2019.3502187

\begin{abstract}
The agave weevil Scyphophorus acupunctatus Gyllenhal (Coleoptera: Dryophthoridae) is the main insect pest of wild and cultivated agaves in Mexico and in other countries. The management of this pest is complicated because to its cryptic habits. Recently, it has been developed a trapping system based with synthetic pheromone and food bait for monitoring this insect. However, an important part of the any trapping system is to know if any can synergize the response of the insect to the synthetic pheromone. In this study, we evaluated several vegetal tissue and ripped fruits for determining its potential as synergist for the synthetic pheromone for trapping the agave weevil in "agave espadín mezcal", in Tlaltizapán, Morelos state. The vegetal evaluated were: "maguey espadín criollo" tissue, "maguey espadín oaxaqueño" tissue, "maguey papalote" tissue, sugarcane tissue, ripped pineapple fruit, ripped banana fruit, ripped guava fruit, ripped apple fruit, and tuberose flower. Our results showed that the best synergists were agave tissue, pineapple, banana submerged in soapy water.
\end{abstract}

Key words: agave weevil; vegetal synergist; pheromone; trapping; agave

Cruz-Faustino, J. J., Figueroa-Castro, P., Alcántara-Jiménez, J. A., López-Martínez, V., SilvaGarcía, F. (2019) Sinergistas vegetales para la captura del adulto de Scyphophorus acupunctatus Gyllenhal, en trampas con feromona, en Agave angustifolia Haw., en Morelos, México. Acta Zoológica Mexicana (nueva serie), 35, 1-9. https://doi.org/10.21829/azm.2019.3502187 
RESUMEN. Scyphophorus acupunctatus Gyllenhal (Coleoptera: Dryophthoridae) es el insecto plaga más importante de diversas especies de agave silvestre y cultivadas en México y otros países. El manejo de este insecto se dificulta debido a los hábitos bio-ecológicos del insecto. Recientemente, se ha desarrollado un sistema de trampeo basado en feromona sintética y cebo alimenticio para monitorear a este insecto. Sin embargo, es importante conocer algunos vegetales que pueden sinergizar la respuesta de este picudo a la feromona sintética. En este estudio, se evaluaron diversos vegetales en trampas colocadas en una plantación de agave espadín, en Tlaltizapán, Morelos. Los sinergistas vegetales evaluados fueron: tejido vegetal de maguey mezcalero espadín criollo (Agave angustifolia Haw.), espadín oaxaqueño (Agave angustifolia Haw.) y maguey mezcalero papalote (Agave cupreata Trel.), tejido de caña de azúcar, fruta madura de piña, plátano, guayaba y manzana, y flor de nardo. Se encontró que los mejores sinergistas fueron tejido de agaves, piña y plátano sumergidos en el agua jabonosa de la trampa.

Palabras clave: picudo del agave; sinergistas vegetales; feromona; trampeo; agave

\section{INTRODUCTION}

The espadín maguey (Agave vivipara L. =Agave angustifolia Haw.), is essential for mezcal production in Mexico, and is a good source of employment and incomings for families of rural zones of Guerrero and Morelos (F. S. G. and P. F. C., unpublished data). The agave production is affected by several problems as diseases, weeds, and pest insects (Valenzuela, 2003; CRT, 2005), in the case of insect pests the most important species is the agave weevil (Scyphophorus acupunctatus Gyllenhal) (González et al., 2007) which attacks several Agave species including the henequen (Agave fourcroydes Lem.) (Halffter, 1957), blue agave (Agave tequilana Weber) (Solís-Aguilar et al., 2001) and mezcal maguey (Agave angustifolia Haw. and Agave cupreata Trel. \& Berger) (Aquino et al., 2007; Figueroa-Castro et al., 2016). The weevil larvae drilled the periferic and central part of maguey, sometimes damaging leafs, this feeding habit cause damage the agave root (CRT, 2005; González et al., 2007).

Adults of $S$. acupunctatus frequently are found in the basal leaf or inside the "piña", in high infestations this weevil can be found also in the agave heart and in the "quiote". The adult is present and active during all the year, but is most abundant and active in the rainy season and with high temperatures (Ramírez-Choza, 1993; González et al., 2007; Figueroa-Castro et al., 2013).

In addition to the direct damage caused by larvae and adults (Solís-Aguilar et al., 2001; González et al., 2007; Aquino et al., 2007) this weevil is a transmitter of some pathogens that attack and can cause the died of the agave (Aquino et al., 2011).

The management of this pest is difficult because its cryptic habits, all biological cycle occurs inside the agave plant, when food resource ends, this pest emigrates searching new plantations for colonization, females and/or males (Figueroa-Castro et al., 2015) can start the infestation process also.

One basic tool in integrated pest management programs is the monitoring of pest population density (Rojas et al., 2008), in the case of S. acupunctatus a trapping system based in pheromone and food attractants baited traps has been developed (Ruiz-Montiel et al., 2008; Rodríguez-Rebollar et al., 2012; FigueroaCastro et al., 2013). An important factor for optimizing the trapping system for monitoring or controlling insect pests is the use of ripped fruits or host tissue that works as synergists and increases insect captures (Figueroa-Castro et al., 2017). For different weevil species, researchers had tested several fruits as potential synergists, for example, sugarcane for the west Indian sugarcane weevil (Alpizar et al., 2002), guava fruits for the guava weevil (González et al., 2010). For agave weevil tuberose bulbs (García-Ramírez et al., 2014), agaves, pine apple, and banana (Figueroa-Castro et al., 2017) had been evaluated. 
However, until now, the most common synergist source for agave weevil is fresh agave tissue (Figueroa-Castro et al., 2017; Figueroa-Castro et al., 2018), although it is important to know if other fruits and tissue can work as synergist for increasing the captures of this weevil in pheromone-baited traps. With the objective of found more options of synergists that increase the number of weevils trapped per trap, we evaluated several vegetal fruits and tissues as synergists in pheromone-baited in espadín agave.

\section{MATERIALS AND METHODS}

This research was performed in a "maguey espadín" (Agave angustifolia Haw.) plantation in Barranca Honda, Tlaltizapan, Morelos, Mexico (five hectares, five years-old). We conducted three consecutive field trials (December 2017 to February 2018), in each trial were evaluated different food attractants to determine the best alternative vegetal synergist to aggregation synthetic pheromone for trapping the agave weevil.

The trap design used was TOCCIA of 4 liters, white color (Figueroa-Castro et al., 2016). The killing agent for trapping weevils was 1 liter of soapy water at 5\%. Traps were buried at trap holes (entry) level. Distance between traps was at least $50 \mathrm{~m}$. Traps checking (collected trapped weevils), change of food attractant and killing agent application were biweekly. The synthetic pheromone used was Tequilur ${ }^{\circledR}$ (FeroComps, Mexico City, Mexico), pheromone dispensers were new at start of each experiment. The complete time of this research were three months, each experiment had a month duration.

First experiment. Were evaluated the following treatments: 1) empty trap (without attractants), 2) trap with pheromone without synergist, 3) trap with pheromone $+400 \mathrm{~g}$ of "maguey espadín criollo" (Agave angustifolia Haw.) tissue, 4) trap with pheromone $+400 \mathrm{~g}$ of "maguey espadín oaxaqueño" (Agave angustifolia Haw.) tissue, 5) trap with pheromone $+400 \mathrm{~g}$ of "maguey papalote" (Agave cupreata Trel.) tissue, 6) trap with pheromone $+400 \mathrm{~g}$ of ripped pineapple fruit (Ananas comosus L.), 7) trap with pheromone $+400 \mathrm{~g}$ of ripped banana (Musa paradisiaca L.) fruit, 8) trap with pheromone $+400 \mathrm{~g}$ of sugarcane (Saccharum officinarum L.) tissue, 9) trap with pheromone $+100 \mathrm{~g}$ of tuberose (Polianthes tuberosa L.) flower, and 10) trap with pheromone $+400 \mathrm{~g}$ ripped of guava (Psidium guajava L.) fruit. This experiment was establishment in a completely experimental design with four replications.

Second Experiment. Were evaluated the following treatments: 1) empty trap (without attractants), 2) trap with pheromone without synergist, 3) trap with pheromone $+400 \mathrm{~g}$ of "maguey espadín criollo" tissue, 4) trap with pheromone $+400 \mathrm{~g}$ of "maguey espadín oaxaqueño" tissue, 5) trap with pheromone $+400 \mathrm{~g}$ of "maguey papalote" tissue, 6) trap with pheromone $+400 \mathrm{~g}$ of ripped pineapple fruit, 7) trap with pheromone $+400 \mathrm{~g}$ of ripped banana fruit, 8) trap with pheromone $+400 \mathrm{~g}$ of sugarcane tissue, 9) trap with pheromone $+400 \mathrm{~g}$ of ripped apple (Malus domestica Borkh)fruit, 10) trap with pheromone $+400 \mathrm{~g}$ of ripped guava fruit. This experiment was establishment in a completely experimental design with four replications.

Third experiment. Were evaluated the following treatments: 1) trap with pheromone without synergist, 2) trap with pheromone $+400 \mathrm{~g}$ of ripped banana fruit hanged*, 3) trap with pheromone $+400 \mathrm{~g}$ of ripped banana fruit submerged $\left.{ }^{* *}, 4\right)$ trap with pheromone $+400 \mathrm{~g}$ ripped pineapple fruit hanged, 5) trap with pheromone $+400 \mathrm{~g}$ of ripped pineapple fruit submerged, 6) trap with pheromone $+400 \mathrm{~g}$ of "maguey espadín oaxaqueño" tissue hanged, 7) trap with pheromone $+400 \mathrm{~g}$ of "maguey espadín oaxaqueño" tissue submerged, 8) trap with pheromone $+400 \mathrm{~g}$ of sugarcane tissue hanged, 9) trap with pheromone $+400 \mathrm{~g}$ of sugarcane tissue submerged, 10) trap with pheromone $+400 \mathrm{~g}$ ripped guava fruit hanged, 11) trap with pheromone $+400 \mathrm{~g}$ ripped guava fruit submerged. This experiment was establishment in a completely experimental design with factorial arrangement, with four replications. *hang means that the food bait do not have contact with the soapy water, the food bait was hung in a plastic container with 8 holes of $1 \mathrm{~cm}$ of diameter in the trap. ** Submerged means that the food bait or synergist is in the soapy water. 
Captured weevils were placed in labeled plastic containers, and transported to laboratory for counting and sex classification, according to Ramírez-Choza (1993).

Collected data was checked for normality (Shapiro-Wilk test) and homogeneity of variances tests, an ANOVA tested treatment means with Tukey $(\alpha=0.05)$. A Chi-squared test was applied to determine differences in the number of females and males caught by treatment.

\section{RESULTS AND DISCUSSIONS}

In the first experiment, we found significant statistical differences between treatments $(F=24.12 ; \mathrm{df}=9$, 30; $P=<0.0001$ ), higher captures were obtained in traps baited with the synthetic pheromone plus any food bait "papalote" (18.50 \pm 5.06$)$, "criollo" (13.25 \pm 0.85$)$ and "oaxaqueño" maguey (16.0 \pm 4.42$)$, tuberose ( $8.5 \pm 2.4)$, sugar cane tissue $(23.0 \pm 3.9)$, pineapple $(28.3 \pm 15.7)$, banana $(22.3 \pm 2.21)$ and guava fruit $(21.8 \pm 1.8)$ than traps baited only with pheromone (0.0). Empty traps did not captured weevils (Fig. 1).

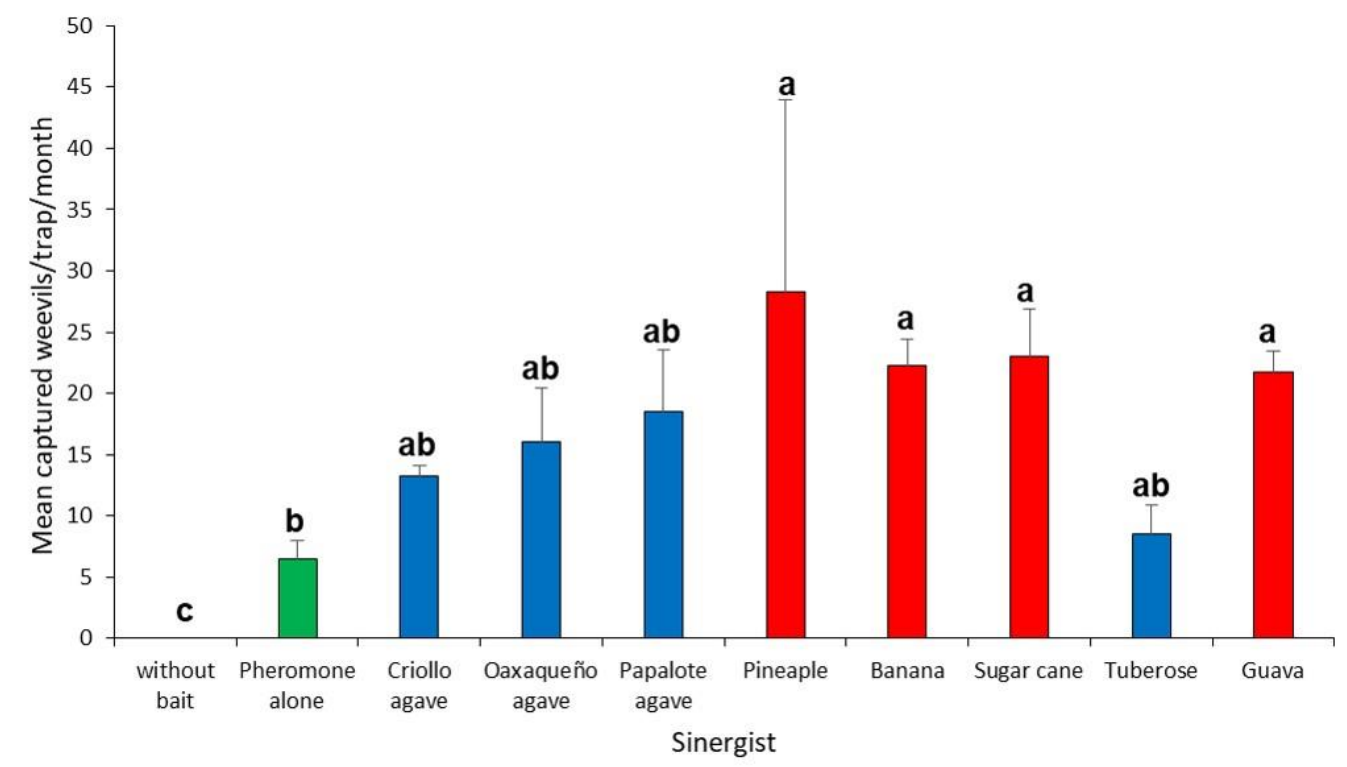

Figure 1. Mean number of captured weevils in pheromone-baited traps with different vegetal synergists in espadín maguey in Barranca Honda, Tlaltizapan, Morelos. Bars with similar letters are not significantly different (Tukey's test, $\alpha=0.05$ ). Means presented in this graph are an average of the four replications.

In the second experiment, significant statistical differences between treatments were detected $(F=$ 3.40; $\mathrm{df}=9,30 ; P=0.0055)$, higher captures were obtained in traps baited with the synthetic pheromone plus pineapple $(10.75 \pm 5.2)$ or banana $(8.75 \pm 1.4)$, than traps baited only with pheromone $(0.8 \pm 0.5)$ or baited with other food baits. Empty traps did not captured weevils (Fig. 2).

In the third experiment, treatments showed statistical differences $(F=2.75$; $\mathrm{df}=10,33 ; P=$ $<0.0139$ ), higher captures were obtained in traps baited with the synthetic pheromone plus any food bait. Traps in which the food bait was placed submerged in the soapy water captured more weevils than traps baited with pheromone alone (Fig. 3).

The fact that some vegetal tissues and some fruits synergized the responses of agave weevils to the synthetic pheromone has been reported previously, Figueroa-Castro et al. (2017) recorded that tissue of 
"papalote" maguey, and ripped fruits (banana and pineapple) worked as synergists increasing number of captured weevils in pheromone-baited traps. In addition, Ruiz-Montiel et al. (2017) evaluated tissue of "pulquero agave", blue agave and ornamental agave and tuberose bulbs, and found that tuberose bulbs were the most attractive for this weevil. Similar responses in other weevils with vegetal tissues or ripped fruits as synergists have been reported (Oehlschlager et al., 1993; Giblin-Davis et al., 1996; Tinzaara et al., 2007; Wibe et al., 2014).

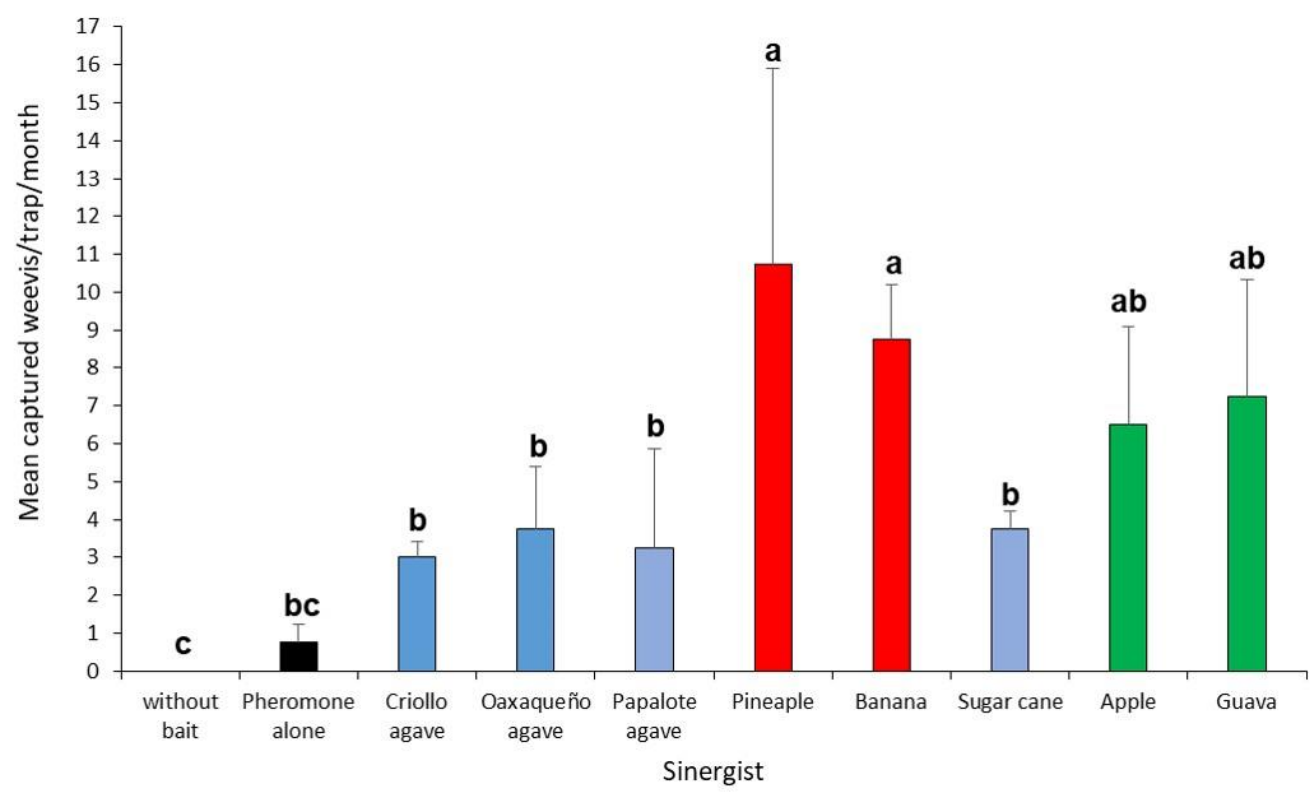

Figure 2. Mean number of captured weevils in pheromone-baited traps with different vegetal synergists in espadín maguey in Barranca Honda, Tlaltizapan, Morelos. Bars with similar letters are not significantly different (Tukey's test, $\alpha=0.05)$. Means presented in this graph are an average of the four replications.

Respect to the synergists, in our study the best food attractants were "papalote" maguey tissue, and banana and pineapple ripped fruits, these baits (banana and pineapple) have been reported previously as food attractants for trapping this and other weevil species. Pineapple was evaluated by García-Ramírez et al. (2014) for trapping this pest on tuberose plant [Polianthes tuberosa L. cv Perla (Asparagaceae)]. Figueroa-Castro et al. (2013) and Figueroa-Castro et al. (2016) used agaves tissue for collecting $S$. acupunctatus in blue agave and mezcal maguey, respectively. Agave tissue, ripped banana fruit and ripped pineapple fruit were reported as synergists for agave weevil by Figueroa-Castro et al. (2017). Banana was tested by Al-Saoud and Ajland (2013) for collecting Rhynchophorus ferrugineus Olivier, and by Sumano et al. (2012) for trapping R. palmarum L. Banana and pineapple fruits appears to be good synergists for agave weevil, with similar captures as reported for agave tissues, but with additional advantages: 1) cheaper, 2) abundant, 3) easy to buy, and 4) with no direct impacts for agave production when agave has high value.

Respect to sexual proportion of captured weevils in most of the traps were captured significantly more females than males (Table 1), data similar to previous reports (Figueroa-Castro et al., 2013; FigueroaCastro et al., 2017; and Figueroa-Castro et al., 2018).

Based on our results, for trapping the agave weevil on cultivated agaves we suggest always to use as vegetable synergists $400 \mathrm{~g}$ of ripped fruit (banana or pineapple) or $400 \mathrm{gr}$ of fresh agave tissue; whatever of these baits submerged in soapy water. 


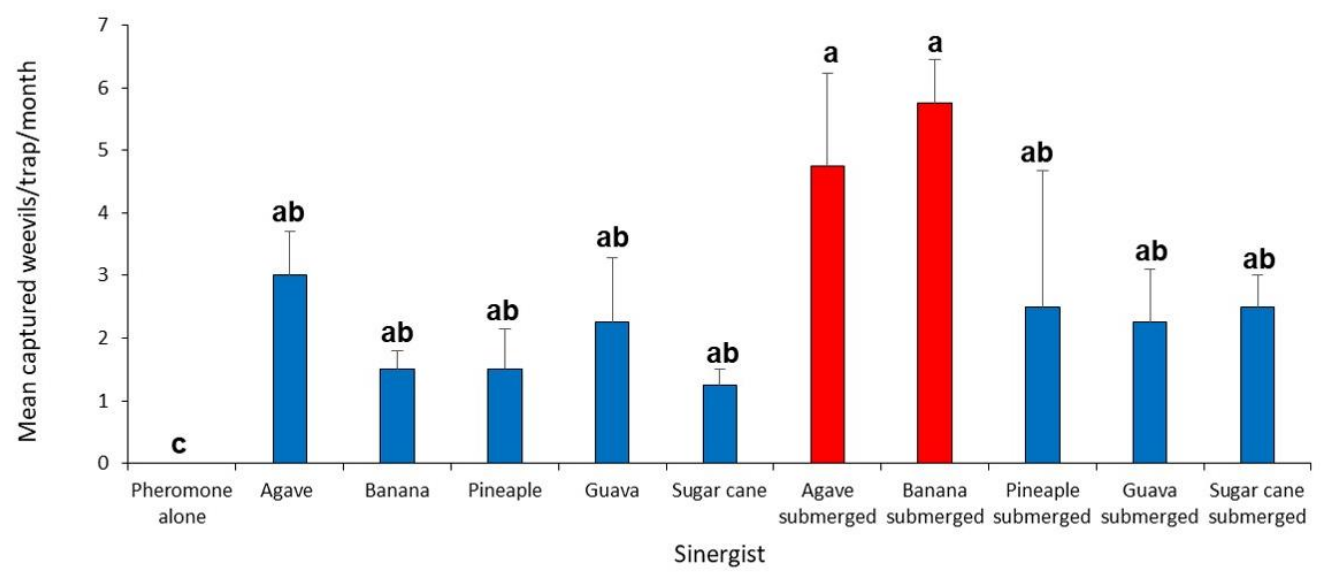

Figure 3. Mean number of captured weevils in pheromone-baited traps with different vegetal synergists in espadín maguey in Barranca Honda, Tlaltizapan, Morelos. Bars with similar letters are not significantly different (Tukey's test, $\alpha=0.05)$. Means presented in this graph are an average of the four replications.

Table 1. Percent of females and males captured in pheromone-baited traps with different vegetal synergists.

\begin{tabular}{|c|c|c|c|c|c|}
\hline Experiment & Synergist & Females (\%) & Males (\%) & $\mathbf{X}^{2}$ & Pr $>X^{2}$ \\
\hline \multirow[t]{10}{*}{1} & Without bait & 0.00 & 0.00 & NA & NA \\
\hline & Pheromone alone & 69.37 & 30.63 & 15.05 & 0.0001 \\
\hline & Criollo agave & 48.88 & 51.12 & 0.0502 & 0.8228 \\
\hline & Oaxaqueño agave & 73.33 & 26.67 & 21.7716 & $<.0001$ \\
\hline & Papalote agave & 67.03 & 32.97 & 11.6008 & 0.0007 \\
\hline & Pineapple & 64.16 & 35.84 & 8.0202 & 0.0046 \\
\hline & Banana & 59.67 & 40.33 & 3.7404 & 0.0531 \\
\hline & Sugarcane & 58.59 & 41.41 & 2.9515 & 0.0858 \\
\hline & Tuberose & 59.47 & 40.53 & 3.5872 & 0.0582 \\
\hline & Guava & 60.45 & 39.55 & 4.3681 & 0.0366 \\
\hline \multirow[t]{10}{*}{2} & Without bait & 0.00 & 0.00 & NA & NA \\
\hline & Pheromone alone & 66.66 & 33.34 & 11.1022 & 0.0009 \\
\hline & Criollo agave & 82.86 & 17.14 & 43.1912 & $<.0001$ \\
\hline & Oaxaqueño agave & 50.00 & 50.00 & 0.000000 & 1.00000 \\
\hline & Papalote agave & 77.50 & 22.50 & 30.25000 & $<.0001$ \\
\hline & Pineapple & 64.00 & 36.00 & 7.84000 & 0.0051 \\
\hline & Banana & 66.25 & 33.75 & 10.5625 & 0.0012 \\
\hline & Sugarcane & 72.22 & 27.78 & 19.7491 & $<.0001$ \\
\hline & Apple & 73.07 & 26.93 & 21.289 & $<.0001$ \\
\hline & Guava & 41.05 & 58.95 & 3.2041 & 0.0735 \\
\hline \multirow[t]{11}{*}{3} & Pheromone alone & 0.00 & 0.00 & NA & NA \\
\hline & Agave & 50.00 & 50.00 & 0.000 & 1.000 \\
\hline & Banana & 50.00 & 50.00 & 0.000 & 1.000 \\
\hline & Pineapple & 66.67 & 33.33 & 11.116 & 0.001 \\
\hline & Guava & 45.00 & 55.00 & 1.000 & 0.317 \\
\hline & Sugarcane & 16.67 & 83.34 & 44.449 & $<.0001$ \\
\hline & Agave submerged & 57.22 & 42.78 & 2.085 & 0.149 \\
\hline & Banana submerged & 61.89 & 38.11 & 5.655 & 0.017 \\
\hline & Pineapple submerged & 70.00 & 30.00 & 16.000 & $<.0001$ \\
\hline & Guava submerged & 65.00 & 35.00 & 9.000 & 0.003 \\
\hline & Sugarcane submerged & 35.72 & 64.28 & 8.157 & 0.004 \\
\hline
\end{tabular}




\section{CONCLUSIONS}

In conclusion, the best synergists were agave tissue, pineapple and banana, all submerged in soapy water because reach the highest captures of agave weevils.

ACKNOWLEDGEMENTS. We thank to Gloria Luna Alejandro, Daniel Cuevas López, Martín Pérez Figueroa and Francisco Santillán for their unvaluable help in field experiments.

\section{LITERATURE CITED}

Alpizar, D., Fallas, M., Oehlschlager, A. C., Gonzalez, L. M., Chinchilla-López, C. M., BulgarelliMora, J. M. (2002) Pheromone mass trapping of the West Indian sugarcane weevil and the American palm weevil Coleoptera: Curculionidae in palmito palm. Florida Entomologist, 85, 426430.

http://journals.fcla.edu/flaent/article/view/75119/72777

Al-Saoud, A., Ajlan, A. (2013) Effect of date fruits quantity on the numbers of red palm weevil Rhynchophorus ferrugineus (Olivier), captured in aggregation pheromone traps. Agriculture and Biology Journal of North America, 4, 496-503.

DOI: 10.5251/abjna.2013.4.4.496.503

Aquino, B. T., Iparraguire C. M. A., Ruiz V. J. (2007) Scyphophorus acupunctatus (=interstitialis) Gyllenhal (Coleoptera: Curculionidae). Plaga del agave mezcalero: pérdidas y daños en Oaxaca, México. Revista UDO Agrícola, 7, 175-180. www.bioline.org.br/pdf?cg07018

Aquino, B. T., Ruiz V. J., Giron, P., Pérez, P. S. R., Martínez, T. S. H., Silva, R. M. E. (2011) Interrelationships of the agave weevil Scyphophorus acupunctatus (Gyllenhal), Erwinia carotovora (Dye), entomopathogenic agents and agrochemicals. African Journal of Biotechnology, 68, 1540215406.

DOI: $10.3958 / 059.038 .0310$

CRT (Consejo Regulador del Tequila) (2005) Plagas y Enfermedades del Agave tequilana Weber, var. azul. Consejo Regulador del Tequila, A. C. Editorial Pandora. 123 p.

Figueroa-Castro, P., Solís-Aguilar, J. F., González-Hernández, H., Rubio-Cortés, R., HerreraNavarro, E. G., Castillo-Márquez, L. E., Rojas, J. C. (2013) Population dynamics of Scyphophorus acupunctatus (Coleoptera: Curculionidae) on blue agave. Florida Entomologist, 96, 1454-1462.

DOI: $10.1653 / 024.096 .0425$

Figueroa-Castro, P., González-Hernández, H., Carrillo-Sánchez, J. L., del Real-Laborde, J. I., SolísAguilar, J. F., Rojas, J. C. (2015) Ambos sexos de Scyphophorus acupunctatus (Coleoptera: Dryophthoridae) pueden iniciar la colonización de la planta de agave (Asparagaceae). Acta Zoológica Mexicana (nueva serie), 31, 495-497.

http://azm.ojs.inecol.mx/index.php/azm/article/view/1097

Figueroa-Castro, P., López-Martínez, V., Hernández-Ruiz, A., Silva-García, F., Campos- Figueroa, M. (2016) Determining the best pheromone-baited traps for capturing Scyphophorus acupunctatus (Coleoptera: Dryophthoridae) in mezcal agave. Florida Entomologist, 99, 790-792.

DOI: 10.1653/024.099.0437

Figueroa-Castro, P., López-Martínez, V., Silva-García, F., González-Hernández, H. (2017) Food attractants to increase pheromone-baited trap performance for Scyphophorus acupunctatus (Coleoptera: Dryophthoridae) in mezcal maguey. Florida Entomologist, 100 (1), 203-205.

DOI: $10.1653 / 024.100 .0135$ 
Figueroa-Castro, P., González-Hernández, H. Carrillo-Sánchez, J. L. Solís-Aguilar, J. F., del RealLaborde, J. I. Rubio-Cortés, R., Rojas, J. C. (2018) Amount and bagging of the bait food affect the captures of Scyphophorus acupunctatus (Coleoptera: Curculionidae) by pheromone-baited traps. Florida Entomologist, 101 (1), 6-11.

DOI: $10.1653 / 024.101 .0103$

García-Ramírez, M. J., López-Martínez, V., Alia-Tejacal, I., Andrade-Rodríguez, M., Rojas, J. C. (2014) Influence of trap color and food bait on the catches of Scyphophorus acupunctatus by pheromone-baited traps in tuberose crop. Journal of the Kansas Entomological Society, 87, 96-101. DOI: 10.2317/JKES130222.1

Giblin-Davis, R. M., Oehlschlager, A. C., Pérez, A., Gries, G., Gries, R., Weissling, T. J., Chinchilla, C. M., Peña, J. E, Hallett, R. H., Pierce J. H. D., González L. M. (1996) Chemical and behavioral ecology of palm weevils (Curculionidae: Rhynchophorinae). Florida Entomologist, 79, 153-167.

DOI: $10.2307 / 3495812$

González, H. H., Solís, A. J. F., Pacheco, S. C., Flores, M. F. J., Rubio, C. R., Rojas, J. C. (2007) Insectos barrenadores del agave tequilero, pp. 39-67. En: H. González Hernández, J. I. del Real Laborde, J. F. Solís Aguilar [Eds.], Manejo de Plagas del Agave Tequilero. Colegio de Postgraduados and Tequila Sauza, S.A. de C.V., Zapopan, Jalisco, México.

González-Gaona, E., Tafoya-Rangel, F., Padilla-Ramírez, J. S., Lozano-Gutiérrez, J., España-Luna, M. P. (2010) Detection strategies for adults of the guava weevil Conotrachelus spp. Acta Horticulturae, 849, 293-300.

DOI: 10.17660/ActaHortic.2010.849.34

Halffter, G. (1957) Plagas que afectan a las distintas especies de agave cultivadas en México. Dirección General de Defensa Agrícola. SAG. México, D.F.

Oehlschlager, A. C., Chinchilla, C. M., González, L. M., Jiron, L. F., Mexzon, R., Morgan, B. (1993) Development of a pheromone-based trapping system for Rhynchophorus palmarum (Coleoptera: Curculionidae). Journal of Economic Entomology, 86, 1381-1392.

DOI: $10.1093 /$ jee/86.5.1381

Ramírez-Choza, J. L. (1993) Max del henequén Scyphophorus interstitialis Gylh. Bioecología y control. Serie: Libro Técnico. Centro de Investigación Regional del Sureste. Instituto de Investigaciones Forestales, Agrícolas y Pecuarias. Secretaría de Agricultura, Ganadería y Recursos Hidráulicos. Mérida, Yucatán, México.

Rodríguez-Rebollar, H., Rojas, J. C., González-Hernández, H., Ortega-Arenas, L. D., EquihuaMartínez, A., del Real-Laborde, J. I., López-Collado, J. (2012) Evaluación de un cebo feromonal para la captura del picudo del agave (Coleoptera: Curculionidae). Acta Zoológica Mexicana (nueva serie), 28, 73-85.

http://azm.ojs.inecol.mx/index.php/azm/article/view/817

Rojas, J. C., Malo, E. A., Macías, S. J. E. (2008) Uso de semioquímicos en el manejo integrado de insectos plaga, pp: 167-182. En: J. Toledo, F. Infante (Eds.). Manejo Integrado de Plagas. Editorial Trillas. México, D.F. México.

Ruiz-Montiel, C., García-Coapio, G., Rojas, J. C., Malo, E. A., Cruz-López, L., del Real, I., GonzálezHernández, H. (2008) Aggregation pheromone of the agave weevil, Scyphophorus acupunctatus. Entomologia Experimentalis et Applicata, 127, 207-217.

DOI: $10.1111 / \mathrm{j} .1570-7458.2008 .00703 . x$

Ruiz-Montiel, C., Ramón-Domínguez, C. I., Domínguez-Reyes, L., Ainza-Zarate, R., Mendoza-López, M. R. (2017) Efecto de la trampa y atrayente sobre Scyphophorus acupunctatus en agave. Southwestern Entomologist, 42 (1), 237-247. https://doi.org/10.3958/059.042.0121

Solís-Aguilar, J. F., González-Hernández, H., Leyva-Vázquez, J. L., Equihua-Martínez, A., FloresMendoza, F. J., Martínez-Garza, A. (2001) Scyphophorus acupunctatus Gyllenhal, plaga del agave tequilero en Jalisco, México. Agrociencia, 35 (6), 663-670.

https://www.redalyc.org/pdf/302/30200609.pdf. 
Sumano, D., Sánchez, S., Romero J., Sol, A. (2012) Eficacia de captura de Rhynchophorus palmarum L. (Coleoptera: Dryophthoridae) con diferentes diseños de trampas en Tabasco, México. Fitosanidad, $16(1), 43-78$. http://www.scielo.org.co/pdf/rcen/v41n1/v41n1a04.pdf.

Tinzaara, W., Gold, C. S., Dicke, M., Huis, A. V., Ragama, P. E. (2007) Host plant odours enhance the responses of adult banana weevil to the synthetic aggregation pheromone Cosmolure ${ }^{\circledR}$. International Journal of Pest Management, 53, 127-137.

DOI: 10.1080/09670870701191963

Valenzuela, Z. A. G. (2003) El agave tequilero, su cultivo y su industria de México. Tercera edición. Editorial Mundi Prensa. Guadalajara, Jalisco.

Wibe, A., Borg-Karlson, A. K., Cross, J., Bichao, H., Fountain, M., Liblikas, I., Sigsgaard, L. (2014) Combining 1,4-dimethoxybenzene, the major flower volatile of wild strawberry Fragaria vesca, with the aggregation pheromone of the strawberry blossom weevil Anthonomus rubi improves attraction. Crop Protection, 64, 122-128.

https://doi.org/10.1016/j.cropro.2014.06.016 